\title{
Investigation of the effect of non-uniform heat distribution of microwave on the mortality rates of some plants
}

\section{Mikrodalganın düzgün olmayan ısı dağılımının bazı bitkilerin ölüm oranlarına etkisinin araştırılması}

\author{
Hasan SAHIN ${ }^{1 *}$ iD, \\ ${ }^{1}$ Department of Mechatronics, Harran University, Sanliurfa, 63200, Turkey \\ ${ }^{1}$ https://orcid.org/0000-0002-3977-4252
}

To cite this article:

Sahin, H. (2021). Investigation of the effect of non-uniform heat distribution of microwave on the mortality rate of some plants. Harran Tarım ve Gıda Bilimleri Dergisi, 25(3): 293-303.

DOI: $10.29050 /$ harranziraat.885282

*Address for Correspondence: Hasan SAHIN

e-mail:

hsahin@harran.edu.tr

Received Date:

23.02.2021

Accepted Date:

02.07.2021

(C) Copyright 2018 by Harran University Faculty of Agriculture. Available on-line at www.dergipark.gov.tr/harranziraat

\section{ABSTRACT}

Weeds, cause significant losses in agricultural production and are mostly controlled by herbicides, which are harmful to the environment. An alternative method that can be applied instead of these chemicals that pollute the soil and water is the microwave weed control method. But, one of the main problems with the microwave weed control method is the non-uniform heat distribution. This study aims to investigate the effect of non-uniform heat distribution on the mortality rate in the microwave weed control method by the NDVI (Normalized Difference Vegetation Index) technique. The NDVI technique has been used for the first time in this study to determine the mortality rate in microwave weed control. Mortality rates in one-week germinated Lepidium sativum (cress) and Hordeum vulgare (barley) grasses that were exposed to microwave energy for 10, 20, and 30 seconds were measured. It was determined that a higher rate of mortality occurred in the uniform heat distribution condition, compared to the non-uniform heat distribution $(p<0.05)$. Mortality rates in both Hordeum vulgare (barley) and Lepidium sativum (cress) grasses increased as the microwave application time increased. The highest mortality rate occurred in Lepidium sativum (cress) grass (69.81\%) and Hordeum vulgare (barley) grass (61.01\%) with uniform heat distribution for 30 seconds. In the non-uniform heat distribution for 10 seconds, an increase was observed in Hordeum vulgare (barley) grass compared to the control group (7.01\%). As a result, it can be said that weed control with microwave energy has the potential to be a good "environmentally friendly alternative method" to chemical weed control methods.

Key Words: Non-chemical, Environmentally friendly, Alternative weed control, NDVI.

Öz

Tarımsal üretimde önemli kayıplara neden olan yabancı otlar, çoğunlukla herbisit adı verilen çevreye zararlı olduğu bilinen kimyasallarla kontrol edilir. Toprağı ve suyu kirleten bu kimyasalların yerine uygulanabilecek alternatif yöntemlerden birisi de mikrodalga ile yabancı ot kontrolü yöntemidir. Ancak, mikrodalga ile yabancı ot kontrolü yöntemiyle ilgili temel sorunlardan birisi, düzgün olmayan ıSı dağılımıdır. Bu çalışmada, mikrodalga ile yabancı ot kontrolünde, düzgün olmayan ISı dağılımının mortalite oranına etkisini NDVI tekniği ile araştırmak amaçlanmıştır. NDVı tekniği, mikrodalga ile yabancı ot kontrolünde mortalite oranı tespiti amacıyla ilk defa bu çalışmada kullanılmıştır. Mikrodalga enerjiye, 10, 20 ve 30 saniye süreyle maruz bırakılan bir haftalık çimlendirilmiş Lepidium sativum (tere) ve Hordeum vulgare (arpa) bitkilerinin mortalite oranları ölçülmüştür. Düzgün ısı dağılımı koşulunda, düzgün olmayan ısı dağılımına göre daha yüksek oranda mortalitenin meydana geldiği tespit edilmiştir ( $p<0.05)$. Mikrodalga uygulama süresi arttıkça hem Hordeum vulgare (arpa), hem de Lepidium sativum (tere) bitkisinde mortalite oranları da artmıştır. En yüksek mortalite, 30 saniye boyunca düzgün ısı dağılımı uygulamasında, \% 69.81 ile Lepidium sativumda (tere) ve \% 61.01 ile Hordeum vulgarede (arpa) meydana gelmiştir. 10 saniye süreli düzgün olmayan ısı dağılımı 
uygulamasında, Hordeum vulgare (arpa) bitkisi çimlenme oranı kontrol grubuna göre \% 7.01 artış gözlenmiştir. Sonuç olarak, mikrodalga enerji ile yabancı ot kontrolünün, kimyasal yabancı ot kontrol yöntemlerine iyi bir "çevre dostu alternatif yöntem" olma potansiyeline sahip olduğu söylenebilir.

Anahtar Kelimeler: Kimyasal olmayan, Çevre dostu, Alternative yabancı ot kontrolü, NDVI.

\section{Introduction}

The most common weed control method is the use of chemicals (herbicides) (Shaner,2014), (Rüegg,2007), (Qasem,2011). However, the possibility of these chemicals getting into drinking water over time, the damage they cause to the soil and the environment has highlighted nonchemical methods of struggle today. The chemicals (herbicides) used in weed control affect the physiological development of weeds and aim to minimize or completely remove economic loss. Necessary researches should be carried out on the elimination of the damage caused by weeds, their prevalence, and intensity, and the determination of important species and the most appropriate methods of struggle (Aslan, 2018), (Koutica, 2010). The yield loss caused by weeds only in wheat plants is around $20-40 \%$ (Erdal, 2020), (Zimdahl, 2018). The methods of control using herbicides are widely used in the control of weeds, as well as in non-agricultural areas. However, in scientific studies (Cengiz et al., 2017) it has been determined that the herbicides detected in drinking water can be separated by the ozone purification method, the norflurazon and oxadiazon leave residues in plants and soil even after one month, and this poses a danger in consumption (Janaki, 2015).

The effects of herbicides on human health as well as on animals such as bees, birds, and fish, microorganisms, and invertebrates are very serious. It also causes cancer in people who are exposed to phenoxy group herbicides, which are widely used around the world. Additionally, it has been stated that triazines are associated with breast cancer, while terbuthylazine causes lung cancer (Mladinic et al., 2012). The known side effects of herbicides include deaths in non-target organisms and long-term effects such as changes in the structure of the ecosystem and the number of species (Solomon et al., 2013).

As the harms of these agricultural chemicals emerge and environmental sensitivity increases, interest in non-chemical alternative control methods (such as microwave and electric current) has increased (Sahin, 2012).

Herbicides such as atrazine and simazine are widely used in agricultural production areas, railway networks, airports, road and sidewalk edges. Besides, restrictions have been imposed on the use of triazines outside of agricultural areas in some countries. It is highly desired by society to give up natural plant production by giving up chemical control methods. However, many farmers prefer the use of herbicides due to their ease of application (Ngowi, 2007).

In studies conducted with microwave energy, it has also been found that it can kill plant roots and seeds buried a few centimeters deep into the soil (Sahin, 2014). Most of the studies conducted under experimental conditions (De Wilde, 2017), aimed to determine the best microwave process based on power, time, and soil moisture to prevent invasive species from germinating and seed embedding depth was taken as $2,12 \mathrm{~cm}$. It was exposed to microwaves by germinating ryegrass and rapeseed to determine the amount of energy required for the destruction of weeds (Valezquez, 2008). As a result, it has been found that it is technically possible to eliminate the herbaceous species already germinated in the field. According to the results obtained, there was a $100 \%$ restriction on the germination of seeds exposed to the microwave for 126 seconds (Sahin, 2014). Microwaves based on high energy can kill weeds very efficiently (Bajwa, 2015). Using microwave radiation as a weed control method seems to be a good alternative because it does not produce chemical residues in the environment (Rana, 2018).

In the soil exposed to microwave energy, it has been determined in the studies (Khan, 2016) that the agricultural product yield increases. In the study on RF (Radio Frequency) exposures for 
germination increase and alfalfa seed improvement, frequency, electric field intensity, seed moisture content, seed temperature, variant change, and practical application possibilities in the seed industry were discussed (Nelson, 2018).

Khalafalah, (2009), study on Hordeum vulgare (barley) seeds, it was stated that high germination rates were obtained after the Hordeum vulgare (barley) seeds were treated with a microwave output power of $400 \mathrm{~W}$. Also, it has been stated that microwave radiation should be tried on different plants to fully understand the effects of cell organelles, enzyme activity, genetic changes, and yield infrastructures (Cretescu, 2013). Miler, (2018), stated that the effect of microwaves on the DNA of plant cells is still uncertain, but it can be very advantageous to use this electromagnetic radiation as a source of change in mutation breeding. In the study performed by applying $2.45 \mathrm{GHz}$ microwave and 4 different power levels, mortality rates ranging from $4 \%$ to $90 \%$ were obtained in wild mustard and wild oat and Lepidium sativum (cress) plants (Sahin, 2015). But, the thermal leaks that occur during microwave applications also cause a significant energy loss (Sahin, 2019). Taheri, (2018), emphasized the necessity of knowing the dielectric properties of agricultural products in thermal processes that use the microwave and radiofrequency. Any misinterpretation negatively affects the perceived value of the microwave weed control technology and predicts the required energy load more than it is (Rana, 2017).

As the world population increases, agricultural cultivation areas decrease, on the contrary. This situation creates an agricultural sustainability problem. Besides, the negative effects of agricultural chemicals on ecology and life are increasing. Instead of herbicides with such obvious negative effects, the development of more environmentally friendly alternative methods should be encouraged. One of the nonchemical weed control methods is the microwave weed control method. This method is new and environmentally friendly, but it is still in the research and trial phase.

\section{Materials and Methods}

In the study, a speed-controlled microwave tunnel with 4 pcs of $1 \mathrm{~kW}$ magnetrons was used as a microwave tunnel (Figure 1). The microwave output power of each magnetron is 850 watts. To obtain uniform heat distribution during microwave application, the test platform was rotated with a 3 watts 6 rpm synchronous motor. The non-uniform heat distribution conditions have been achieved by deactivating the rotary motor. The movement of the tractor in the field conditions was tried to be simulated by using the conveyor belt.
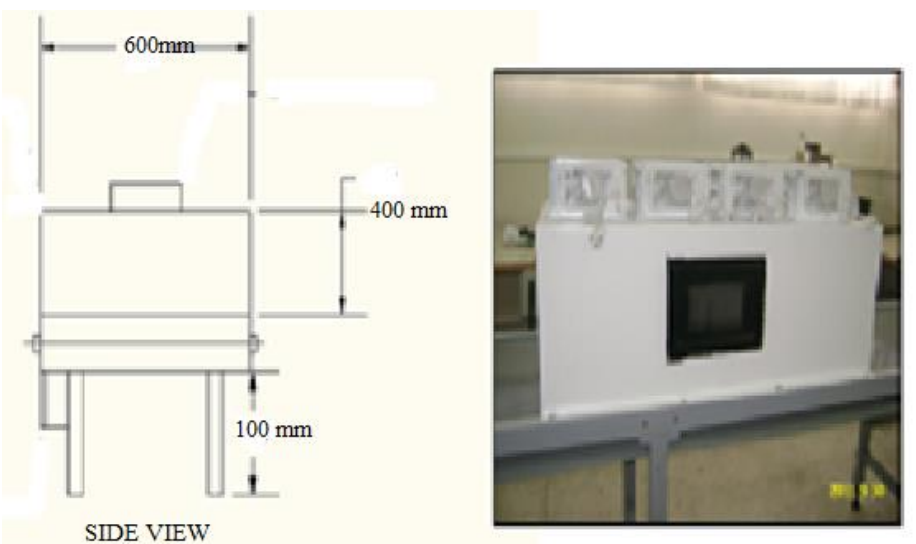

Figure 1. Microwave speed control tunnel with 4 pcs of 1 kW magnetron (Source: Author,2021)

Hordeum vulgare (barley) and Lepidium sativum (cress) seeds that are easily germinated and easily available were preferred. For each recurrence, Hordeum vulgare (barley) and Lepidium sativum (cress) seeds were planted in 4 pots, one for the control group and the other for three samples. All pots were kept in an air conditioning cabinet at $20-22^{\circ} \mathrm{C}$ temperature, average 1000-1200 lux light, and $60-70 \%$ humidity during germination and post-experiment observation. 1 week of germinated Hordeum vulgare (barley) and Lepidium sativum (cress) 
seeds was exposed to a microwave frequency of $2.45 \mathrm{GHz}$ with the help of a magnetron with an output power of $850 \mathrm{~kW}$ for 10, 20, and 30 seconds.

To solve the problem of non-uniform heat distribution in microwave heating, the target material is placed on a circular moving plate. Infield conditions, this problem will be solved by using circular motion microwave guides. For that reason, the samples were exposed to the microwave with the help of a circular motion of a $6 \mathrm{rpm}$ table motor to obtain a uniform heat distribution condition. Non-uniform heat distribution conditions were obtained by exposing the samples to microwave energy while the rotating motor was off. Soil and humidity values of the soil were measured before and after the microwave application.

NDVI (normalized difference vegetation index) Meter: NVDI values before the exposure of plants to microwave and 1 week after application were measured with the Trimble Green Seeker handheld device shown in Figure 2. The emission wavelengths of the device are red $660 \mathrm{~nm}, 25 \mathrm{~nm}$ FWHM, near-infrared $780 \mathrm{~nm}$, and $25 \mathrm{~nm}$ FWHM, and the field of view of the device is $25 \mathrm{~cm}$ at 60 $\mathrm{cm}$ or $50 \mathrm{~cm}$ at $122 \mathrm{~cm}$. The height range is from 60 to120 cm. The normalized difference vegetation index (NDVI) provides information about vegetation viability by measuring the difference between near-infrared reflected from vegetation and the red light absorbed by vegetation. It is a technology for distinguishing bare soil from green plants or forests, detecting plants under stress, and determining the health level of plants.

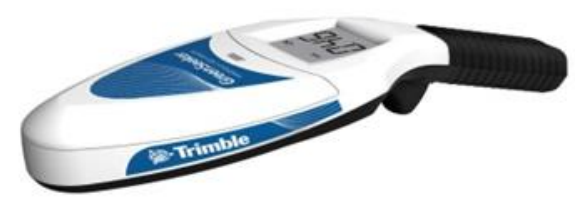

Figure 2. NDVI meter device (Source: Trimble,2021)
$\mathrm{NDVI}_{1}$ (Normalized Difference Vegetation Index) values of the plants were measured and recorded before application. Plants exposed to microwave energy were monitored for 1 week at the appropriate temperature and humid environment and $\mathrm{NDVI}_{2}$ values of plants were measured 1 week after microwave application. Mortality (\%) values occurring in plants were obtained with the help of Equation (1).

$$
\text { Mortality }=\frac{N D V I_{1}-N D V I_{2}}{N D V I_{1}}
$$

Although the normalized difference vegetation index (NDVI) is a widely used method to monitor vegetation dynamics, NDVI values are also known to be deeply affected by various external factors (Arjasakusuma, 2018). When calculating NDVI, in the Normalized Difference Vegetation Index (NDVI) formula, NIR (near infra-red) near-infrared and red (red) channels use, Equation (2).

$$
N D V I=(N I R-R e d) /(N I R+R e d)
$$

This method can help natural resource managers prioritize forest treatment and restoration activities by offering tree mortality rates (Spruce, 2019). Normalized difference vegetation index (NDVI) images derived from processed satellite data were also used in the analysis of the relationship between urban foliage rate and infant mortality in Philadelphia (Schinasi, 2019). A similar study was conducted in Canada using NDVI data (Crouse, 2017). With a machine learning method that distinguishes between crop and weed species based on spectral reflection differences (NDVI), studies on remote sensingbased solutions are also conducted to quickly estimate biodiversity spectral properties (Pantazi, 2016), (Khare, 2018), (Nagler, 2016). NDVI, which is based on the technique that plants reflect energy at the near-infrared wavelength and absorb energy at visible red wavelength, is widely used to monitor changes in climate and agricultural areas (Çelik, 2013).

\section{Statistical analysis}

To compare the mortality rates of Lepidium sativum (cress) and Hordeum vulgare (barley) grass exposed to microwave energy, each variable 
was determined by taking the power of the test at least $80 \%$ and 1 . type error $5 \%$, in calculating the sample width. Descriptive statistics in our study are expressed as a percentage. Z-ratio test was used to compare mortality rates in Lepidium sativum (cress) and Hordeum vulgare (barley) grass, where microwave energy was applied for 10,20 , and 30 seconds in the uniform heat distribution conditions and non-uniform heat distribution conditions. The statistical significance level $(\alpha)$ was taken as $5 \%$ in calculations and Minitab (Statistical Software for Windows, Ver.17) statistical software was used for calculations.

\section{Results and Discussion}

The microwave application results of comparison of mortality rates in the UHD (Uniform Heat Distribution) conditions and NonUHD (Non-Uniform Heat Distribution) conditions for 10, 20, and 30 seconds, in the Lepidium sativum (cress) and Hordeum vulgare (barley) are given. During the same period, when the mortality rates in the UHD conditions and the Non-UHD conditions where the microwave energy is applied are examined; A statistical similarity was found between the mortality rates of Lepidium sativum (cress) grass applied microwave energy in UHD and Non-UHD conditions for 10 seconds ( $p>0.05$ ), (Table 1). In Lepidium sativum (cress) grasses, there was no significant difference between the mortality rates in the heat distributions.

Similarly; A statistical similarity was found between the mortality rates in Hordeum vulgare (barley) grass with microwave energy in UHD and Non-UHD conditions for 10 seconds ( $p>0.05$ ). In other words; In Hordeum vulgare (barley) lawns, there was no significant difference between the mortality rates in these heat distribution conditions.

A statistically significant difference was observed between the mortality rates in Hordeum vulgare (barley) grass where microwave energy was applied in UHD and Non-UHD conditions for 20 seconds $(p<0.05)$. In other words; In Hordeum vulgare (barley) lawns, a significant difference was observed between the mortality rates in these heat distribution conditions.

Table 1. Comparison of mortality rates in microwave exposed Lepidium sativum (cress) and Hordeum vulgare (barley) grasses

\begin{tabular}{|c|c|c|c|c|}
\hline & $\begin{array}{c}\text { Time } \\
\text { (s) }\end{array}$ & $\begin{array}{c}\text { Mortality } \\
\text { rates at UHD } \\
(\%)\end{array}$ & $\begin{array}{c}\text { Mortality rates } \\
\text { at } \\
\text { Non-UHD (\%) }\end{array}$ & $* p$. \\
\hline $\begin{array}{c}\text { Lepidium } \\
\text { sativum } \\
\text { (cress) }\end{array}$ & 10 & 29.63 & 20.02 & 0.141 \\
\hline $\begin{array}{c}\text { Hordeum } \\
\text { vulgare } \\
\text { (barley) }\end{array}$ & 10 & 7.01 & 7.20 & 1.000 \\
\hline \multicolumn{2}{|c|}{$* * \mathrm{p}$} & $<0.001$ & 0.006 & \\
\hline $\begin{array}{c}\text { Lepidium } \\
\text { sativum } \\
\text { (cress) }\end{array}$ & 20 & 57.70 & 36.40 & 0.003 \\
\hline $\begin{array}{c}\text { Hordeum } \\
\text { vulgare } \\
\text { (barley) }\end{array}$ & 20 & 40.10 & 38.09 & 0.772 \\
\hline \multicolumn{2}{|c|}{$* * \mathrm{p}}$. & 0.010 & 0.770 & \\
\hline $\begin{array}{c}\text { Lepidium } \\
\text { sativum } \\
\text { (cress) } \\
\end{array}$ & 30 & 69.81 & 54.90 & 0.027 \\
\hline $\begin{array}{c}\text { Hordeum } \\
\text { vulgare } \\
\text { (barley) }\end{array}$ & 30 & 61.01 & 45.45 & 0.022 \\
\hline \multicolumn{2}{|c|}{$* *$ p. } & 0.179 & 0.155 & \\
\hline
\end{tabular}

* Significance levels of mortality rates occurring in the grass where microwave applied under UHD and Non-UHD conditions according to the results of the Z-ratio test.

** Significance levels of mortality rates in Lepidium sativum (cress) and Hordeum vulgare (barley) grass within the same duration and the same heat distribution conditions according to the results of comparison with Zratio test.,

Here, mortality rates in uniform heat distribution are higher (57.7\%). A statistical similarity was found between the mortality rates in microwave applied Hordeum vulgare (barley) grass in UHD and Non-UHD conditions for 20 seconds ( $p>0.05$ ). In Hordeum vulgare (barley) lawns, there was no significant difference between the mortality rates in these heat distribution conditions.

In the UHD and Non-UHD environments for 30 seconds, a statistically significant difference was observed between the mortality rates in microwave applied Lepidium sativum (cress) grasses ( $p<0.05$ ). In other words; In Lepidium sativum (cress) lawns, a significant difference was observed between the mortality rates in these 
heat distribution conditions. Mortality rates in the UHD conditions occurred at a higher rate (69.8\%).

A statistically significant difference was observed between the mortality rates in microwave energy applied Hordeum vulgare (barley) grasses under UHD and Non-UHD conditions for 30 seconds ( $p$ $<0.05)$. In other words; In Hordeum vulgare (barley) lawns, a significant difference was observed between the Mortality Rates in these heat distribution conditions. Mortality rates in the UHD conditions occurred at a higher rate (61.0\%).

Comparison results of mortality rates in Lepidium sativum-Lepidium sativum (cress) and Hordeum vulgare-Hordeum vulgare (barley) grass in the same periods and the same heat distribution conditions:

A statistically significant difference was observed between the mortality rates in the microwave energy applied Lepidium sativum (cress) and Hordeum vulgare (barley) grasses for 10 seconds, in the UHD conditions ( $p<0.05)$. In the Lepidium sativum (cress) and Hordeum vulgare (barley) grasses, a significant difference was observed between the mortality rates in these heat distribution conditions. Here, the mortality rate in Lepidium sativum (cress) grasses is higher than that of Hordeum vulgare (barley) (29.63\%), (Figure 3).

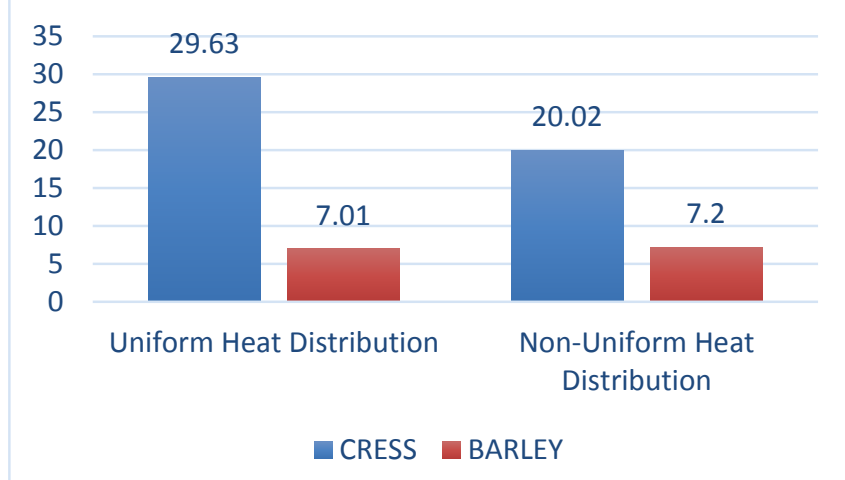

Figure 3. Mortality rates in Hordeum vulgare (barley) and Lepidium sativum (cress) grasses for $10 \mathrm{~s}$ microwave exposed in UHD and Non-UHD conditions

A statistically significant difference was observed between the mortality rates in the Lepidium sativum (cress) and Hordeum vulgare (barley) lawns applied in microwave energy for 20 seconds in the UHD conditions $(p<0.05)$. In the
Lepidium sativum (cress) and Hordeum vulgare (barley) grass, a significant difference was observed between the mortality rates in these heat distribution conditions. Here, the mortality rate in Lepidium sativum (cress) grass is higher than that of Hordeum vulgare (barley) (57.7\%), (Figure 4).

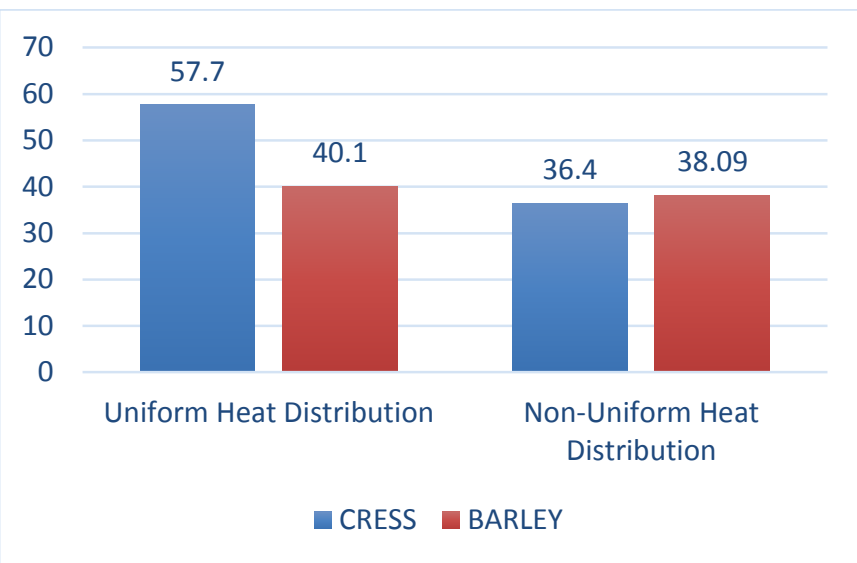

Figure 4. Mortality rates in Hordeum vulgare (barley) and Lepidium sativum (cress) grass for 20 s microwave exposed in UHD and Non-UHD conditions

A statistical similarity was found between the mortality rates in Lepidium sativum (cress) and Hordeum vulgare (barley) grasses, in which microwave energy was applied in the Non-UHD environment for 30 seconds ( $p>0.05)$. In the Lepidium sativum (cress) and Hordeum vulgare (barley) grasses, there was no significant difference between the mortality rates in these heat distribution conditions (Figure 5).

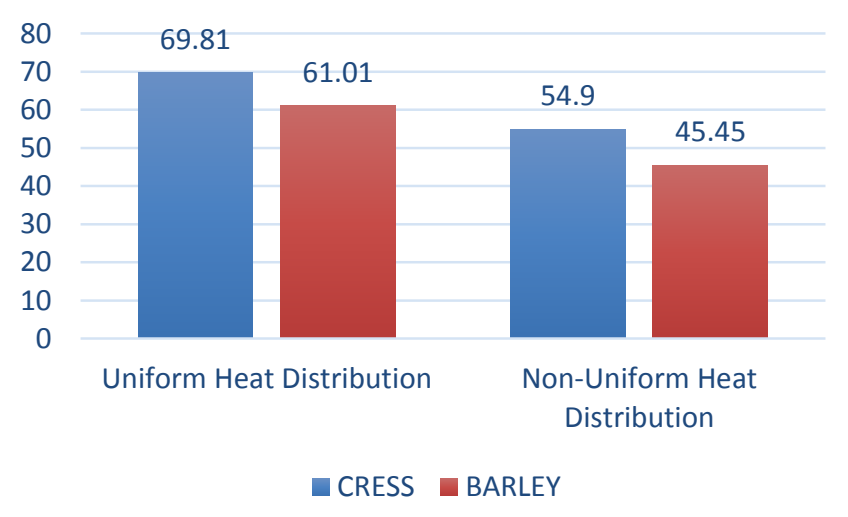

Figure 5. Mortality rates in Hordeum vulgare (barley) and Lepidium sativum (cress) grasses for 30s microwave exposed in UHD and Non-UHD conditions

Looking at the mortality rates in Hordeum vulgare (barley) and Lepidium sativum (cress) 
grass for 10, 20, and 30s in the UHD conditions

(Figure 6); It can be observed that, mortality rates in Lepidium sativum (cress) grasses are higher in all 10s, 20s, and 30s applications.

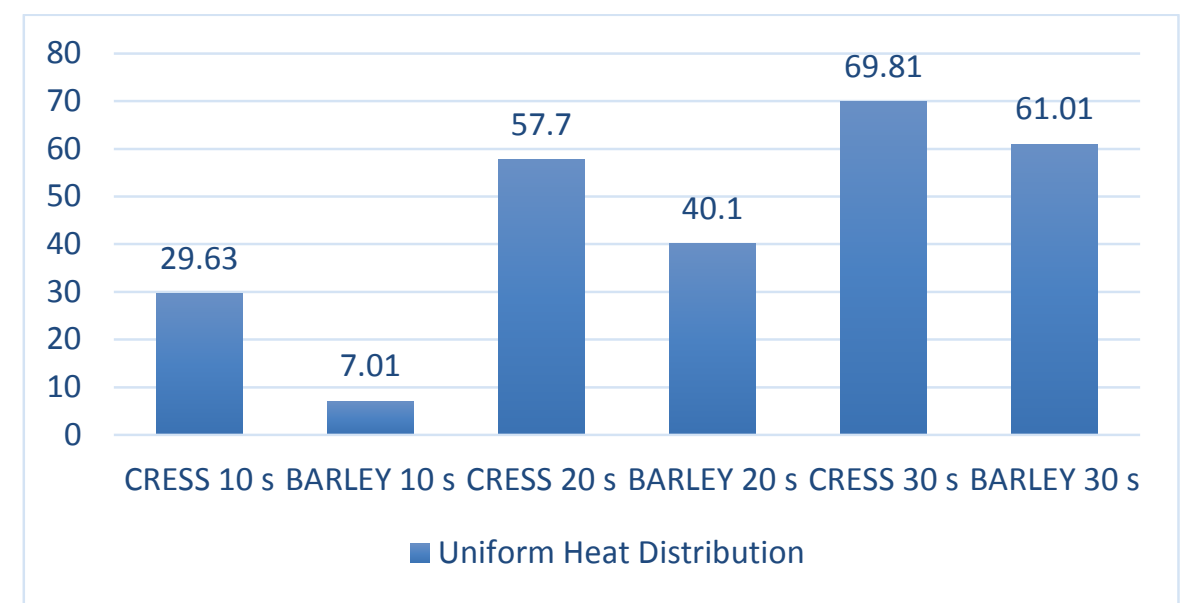

Figure 6. Mortality rates in Hordeum vulgare (barley) and Lepidium sativum (cress) grasses microwave energy exposed for 10, 20, and 30 seconds in UHD conditions

In non-UHD conditions, when the mortality rates in Hordeum vulgare (barley) and Lepidium sativum (cress) grass were examined for 10, 20, and 30s (Figure 7); Mortality rates in Lepidium sativum (cress) grass were higher in all 10s, 20s, and 30s applications. As the microwave exposure time increases, mortality rates increase in both plant species. This result was observed in both UHD conditions and Non-UHD conditions.

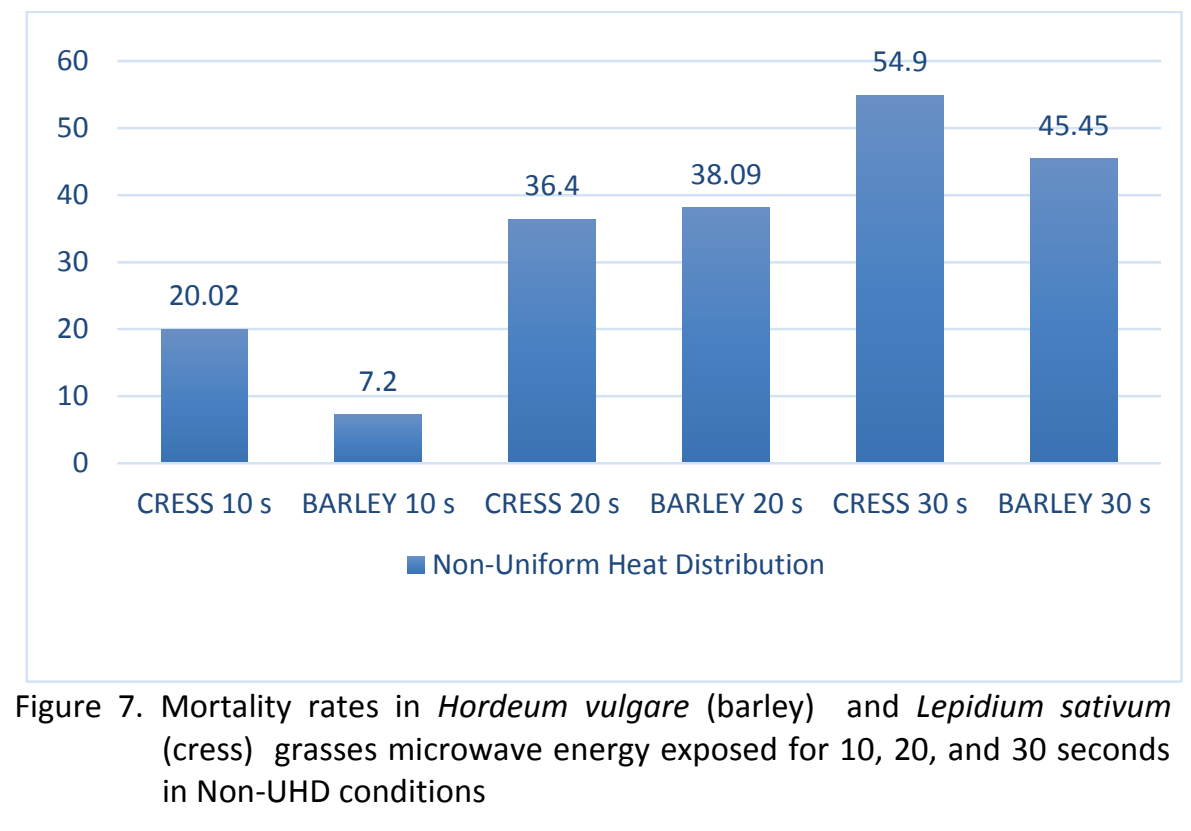

In non-UHD conditions, when the mortality rates occurring in Hordeum vulgare (barley) and Lepidium sativum (cress) grasses for 20 and 30s are examined; It was observed that mortality rates in Lepidium sativum (cress) grass are higher in all 10s, 20s, and 30s applications. As the microwave exposure time increases, mortality rates increase in both plant species (Figure 8). 


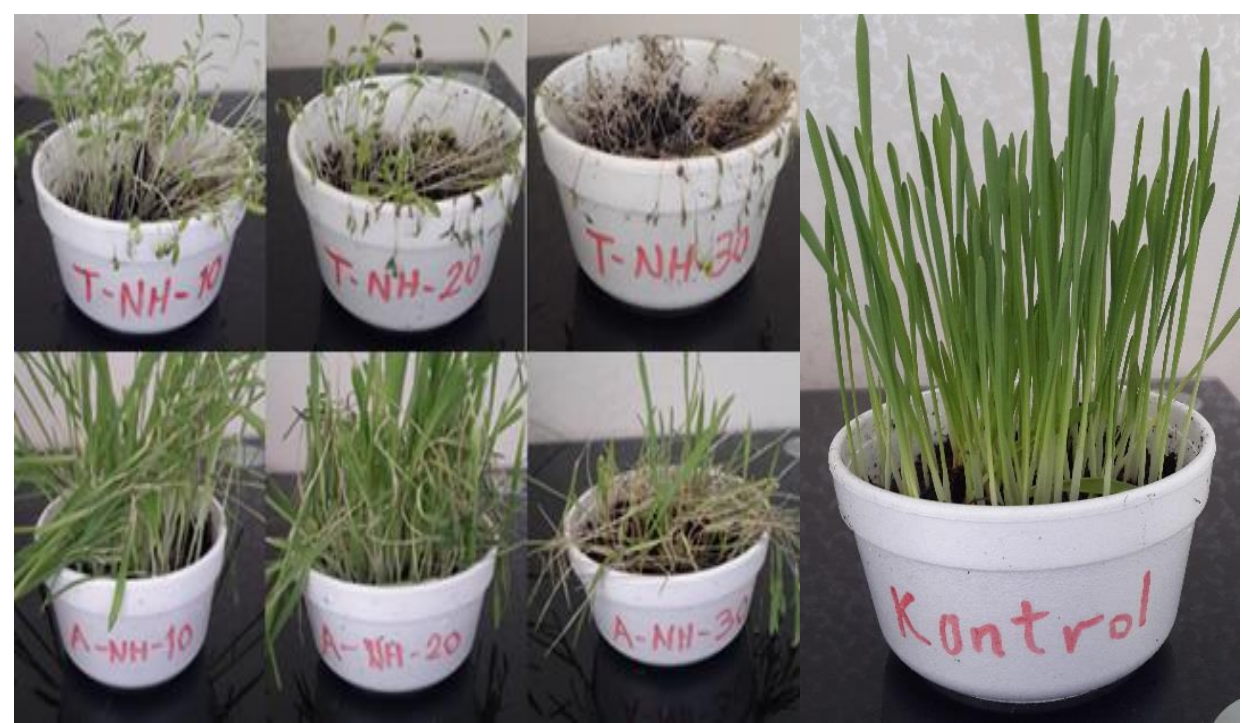

Figure 8. 10, 20, and 30 seconds microwave exposed Lepidium sativum (cress) and Hordeum vulgare (barley) grasses in Non-UHD conditions

When the mortality rates that occur in 10, 20, and 30 s of Hordeum vulgare (barley) and Lepidium sativum (cress) grass under UHD conditions were examined; It was observed that the mortality rates occurring in Lepidium sativum (cress) grass was higher in all 10s, 20s, and 30s applications compared to Hordeum vulgare (barley) grass. As the microwave exposure time increases, mortality rates increase in both plant species (Figure 9).

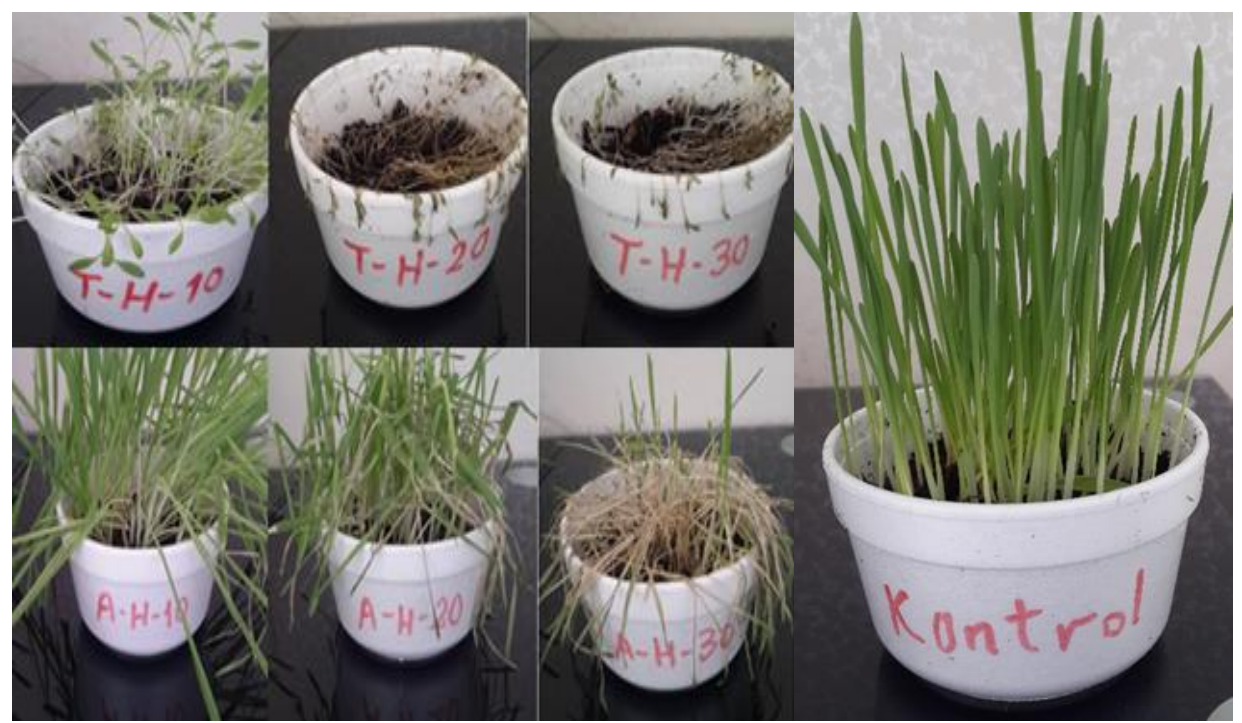

Figure 9. 10, 20, and 30 seconds microwave exposed Lepidium sativum (cress) and Hordeum vulgare (barley) grasses in UHD conditions

Mortality rates and soil temperature changes occurring in Hordeum vulgare (barley) and Lepidium sativum (cress) grasses for 10, 20, and 30 s in UHD and Non-UHD conditions; It shows that as the microwave exposure time increases, the soil temperature increases, and accordingly, the mortality rates increases. As a result, there was an increase in soil temperatures both in the UHD and Non-UHD conditions along with the microwave application time (Table 2).
Table 2. Mortality rates and $\Delta \mathrm{t}$ change for $10 \mathrm{~s}$, the $20 \mathrm{~s}, 30 \mathrm{~s}$ in uniform and non-uniform heat distribution

\begin{tabular}{l|c|c|c|c|c}
\hline & $\begin{array}{c}\text { Time } \\
(\mathrm{s})\end{array}$ & $\begin{array}{c}\text { UHD } \\
\text { Mortality } \\
(\%)\end{array}$ & $\begin{array}{c}\Delta \mathrm{t} \\
\left({ }^{\circ} \mathrm{C}\right)\end{array}$ & $\begin{array}{c}\text { Non-UHD } \\
\text { Mortality } \\
(\%)\end{array}$ & $\begin{array}{c}\Delta \mathrm{t} \\
\left({ }^{\circ} \mathrm{C}\right)\end{array}$ \\
\hline \multirow{3}{*}{$\begin{array}{l}\text { Lepidium } \\
\text { sativum } \\
\text { (cress) }\end{array}$} & 10 & 29.63 & 9.20 & 20.02 & 7.50 \\
\cline { 2 - 6 } & 30 & 57.70 & 20.30 & 36.40 & 17.20 \\
\cline { 2 - 6 } & Control & 69.81 & 23.00 & 54.90 & 20.40 \\
\hline \multirow{3}{*}{$\begin{array}{l}\text { Hordeum } \\
\text { vulgare } \\
\text { (barley) }\end{array}$} & 10 & -7.01 & 7 & 7.20 & 6.20 \\
\cline { 2 - 6 } & 30 & 40.10 & 16.20 & 38.09 & 12.9 \\
\cline { 2 - 6 } & Control & 61.01 & 19.90 & 45.45 & 18.4 \\
\hline
\end{tabular}


In weed control and other microwave thermal applications, one of its main problems is nonuniform heat distribution. This problem causes non-uniform heating and energy loss (Fakhouri, 1993), (Funawatashi, 2003), (Sahin, 2012), (Sahin, 2014), (Sahin, 2015).

A difference was observed between the mortality rates of plants microwave energy applied for 10, 20, and $30 \mathrm{~s}$, under UHD and Non-UHD conditions.

Under UHD conditions, an increase of approximately $7 \%$ was observed in Hordeum vulgare (barley) grasses that were microwaved for $10 \mathrm{~s}$ (Table 2). Microwave and electric current applications at low power levels may cause an increase in germination rate in plants (Sahin, 2012), (Sahin, 2014), (Sahin, 2015), (Sahin 2017), (Sahin, 2020), (Bajwa, 2015).

As the microwave application time increases $(10,20$, and 30 seconds) in UHD conditions, an increase in mortality rates observed in plants (except UHD, $10 \mathrm{~s}$, Hordeum vulgare (barley) ) was observed (Table 2), (UHD Lepidium sativum (cress); 29.63\%, 57.70\%, 69.81\%, UHD Hordeum vulgare (barley); 40.10\%, 61.01\%, respectively), (Sahin, 2014), (Sahin, 2015), (Sahin 2017), (Cretescu, 2013), (De Wilde, 2017).

In UHD and Non-UHD conditions for 10, 20, and $30 \mathrm{~s}$, mortality rates in Lepidium sativum (cress) grass was higher than Hordeum vulgare (barley) grass. This is thought to be due to physical property differences (stem thickness, leaf shape, total plant mass) between plant grass.

Besides, in electrical and microwave applications, the properties of weed species and soil such as electrical resistance $(R)$, impedance $(Z)$, dielectric constant $\left(\varepsilon^{\prime}\right)$, loss factor $\left(\varepsilon^{\prime \prime}\right)$ and dissipation factor ( $\tan \delta$ ) should be taken into account (Kafarski, et al., 2018), (Taheri et al., 2018). (Van, 2016), (Sahin, 2019).

Microwaves based on high energy can kill weeds very efficiently (Bajwa, 2015). Therefore, the use of microwave radiation as a weed control method seems to be a good alternative because it does not leave any chemical residue in the environment (Rana, 2018).
Rapid urbanization increased per capita water consumption and increased water pollution in parallel with industrial development (Muratoglu, 2020). Besides, the decrease in the capacity of the dam basins due to the accumulation of solids (Güvel,2020) indicates potable water problems that may arise in the future. Land-use changes made for economic development increase pressures especially on sensitive ecosystems (Kuru,2020). In this context, the proliferation of non-chemical weed control methods is important to reduce the use of agricultural chemicals that also cause drinking water pollution.

\section{Conclusion}

One of the main problems in microwave weed control management is the non-uniform heat distribution. This problem causes non-uniform heating, energy loss, and poor heating quality. In this study, it was found that, as the microwave application time increases in UHD conditions, an increase is observed in the mortality rates of plants. It has been observed that the efficiency of the method increases even more when provided in the uniform heat distribution mode. It is thought that as the technologies used in this method are developed, it will be accepted as a more efficient and economical method. To determine the applicability of weed control with microwave under field conditions, it will be tested with a microwave application device to be developed and the results obtained will be reevaluated.

As a result, weed control with microwave energy has the potential to be a good "environmentally friendly alternative method" to chemical weed control methods.

Conflict of Interest: The authors declare that they have no conflict of interest.

Author's Contribution: The experimental design, experiments and data analysis of this article, preparation according to the journal writing rules, and editing works were carried out by Hasan Şahin. 


\section{References}

Arjasakusuma, S., Yamaguchi, Y., Nakaji, T., Kosugi, Y., Shamsuddin, S. A., \& Lion, M. (2018). Assessment of values and trends in coarse spatial resolution NDVI datasets in Southeast Asia landscapes. European Journal of Remote Sensing, 51(1), 863-877.

Arslan, Z. F. (2018). Şanlıurfa ili pamuk tarlalarında sulama sonrası yabancı otlar ile ilgili yaşanan değişimler, sorunlar ve çözüm önerileri. Harran Tarım ve Gıda Bilimleri Dergisi, 22(1), 109-125.

Bajwa, A. A., Mahajan, G., \& Chauhan, B. S. (2015). Nonconventional Weed Management Strategies For Modern Agriculture. Weed Science, 63(4), 723-747.

Brodie, G., Hamilton, S. and Woodworth, J. (2007). "An Assessment of Microwave Soil Pasteurization For Killing Seeds And Weeds," Plant Protection Quarterly, Vol. 22, No. 4, Pp. 143-149, 2007.

Cengiz, M. F., Basancelebi, O., \& Kitis, Y. E. (2017). Glyphosate residues in drinking waters and adverse health effects. The Turkish Journal of Occupational/Environmental Medicine and Safety, $2(1$ (3)), 247-258.

Çelik, M., \& Sönmez, M. (2013a). Kızıltepe İlçesinin Tarımsal Yapısındaki Değişimlerin Modis NDVI Verileri Kullanılarak İzlenmesi ve incelenmesi. Marmara Coğrafya Dergisi, (27), 262-281.

Cretescu, I., Căpriță, R., Velicevici, G., Ropciuc, S., \& Buzamat, G. (2013). The response of Hordeum vulgare (barley) Seedlings to Microwaves at 2.45 $\mathrm{GHz}$. Scientific Papers Animal Science and Biotechnologies, 46(1), 185-191.

De Wilde, M., Buisson, E., Yavercovski, N., Willm, L., Bieder, L., \& Mesléard, F. (2017). Using microwave soil heating to inhibit invasive species seed germination. Invasive Plant Science and Management, 10(3), 262270.

Erdal, A. Üremiş, ì. (2020). Şanlıurfa ili buğday ekim alanlarında bulunan yabancı ot türlerinin, yaygınlık ve yoğunluklarının belirlenmesi. Harran Tarım ve Gıda Bilimleri Dergisi, 24(1), 33-43.

Guvel, S. P., \& Yurtal, R. (2020).Investigation of sedimentation effects on the Seyhan Dam reservoir. Journal of The Faculty of Engineering and Architecture of Gazi University, 35(2), 1015-1025.

Janaki, P., Sharma, N., Chinnusamy, C., Sakthivel, N., \& Nithya, C. (2015). Herbicide residues and their management strategies. Indian Journal of Weed Science, 47(3), 329-344.

Kafarski, Marcin, et al. (2018). Evaluation of apple maturity with two types of dielectric probes. Sensors. 18.1: 121.

Khalafallah, A. A., \& Sallam, S. M. (2009). Response Of Maize Seedlings To Microwaves At $945 \mathrm{Mhz}$. Romanian J. Biophys, 19(1), 49-62.

Khan, M. J., Brodie, G., \& Gupta, D. (2016). Effect of Microwave $(2.45 \mathrm{GHz}$ ) Treatment of Soil on Yield Components of Wheat (Triticum Aestivum L.). Journal of Microwave Power and Electromagnetic Energy, 50(3), 191-200.

Khare, S., Latifi, H., \& Ghosh, S. K. (2018). A multi-scale assessment of invasive plant species diversity using
Pléiades 1A, RapidEye and Landsat-8 data. Geocarto International, 33(7), 681-698.

Koutika, L. S., \& Rainey, H. J. (2010). Chromolaena odorata in different ecosystems: weed or fallow plant? Applied Ecology and Environmental Research, 8(2), 131-142.

Kuru, A., \& Tezer, A. (2020). İçme suyu havzası koruma sınırlarının belirlenmesine yeni yöntem önerisi: Kırklareli barajı içme suyu havzası örneği. Journal of the Faculty of Engineering \& Architecture of Gazi University, 35(1).

Miler, N., \& Kulus, D. (2018). Microwave Treatment Can Induce Chrysanthemum Phenotypic And Genetic Changes. Scientia Horticulturae, 227, 223-233.

Mladinic M, Zeljezic D, Shaposhnikov SA, Collins AR. (2012). The use of FISH-comet to detect c-Myc and TP 53 damage in extended-term lymphocyte cultures treated with terbuthylazine and carbofuran. Toxicology Letters, v. 211, p. 62-69.

Muratoglu, A. (2020). Assessment of the water footprint of production: A case study for Diyarbakir province. Journal of The Faculty of Engineering and Architecture of Gazi University, 35(2), 845-858.

Nagler, P. L., Sridhar, B. M., Olsson, A. D., van Leeuwen, W. J., \& Glenn, E. P. (2016). Hyperspectral Remote Sensing Tools for Quantifying Plant Litter and Invasive Species in Arid Ecosystems. In Hyperspectral Remote Sensing of Vegetation (pp. 396-429). CRC Press.

Nelson, S. O. (2018). Rf Electrical Seed Treatment To Improve Germination. In 2018 Asabe Annual International Meeting (P. 1). American Society of Agricultural and Biological Engineers.

Ngowi, A. V. F., Mbise, T. J., ljani, A. S. M., London, L., \& Ajayi, O. C. (2007). Smallholder vegetable farmers in Northern Tanzania: Pesticides use practices, perceptions, cost and health effects. Crop protection, 26(11), 1617-1624.

Pantazi, X. E., Moshou, D., \& Bravo, C. (2016). Active learning system for weed species recognition based on hyperspectral sensing. Biosystems Engineering, 146, 193-202.

Qasem, J. R. (2011). Herbicides applications: problems and considerations. INTECH Open Access Publisher.

Rana, A., \& Derr, J. F. (2017). Determining The Microwave Radiations Exposure Level Needed For Weed Control Using A Stationary and Running Belt Microwave Radiations Applicator System. Journal of Environmental Horticulture, 35(2), 58-65.

Rana, A., \& Derr, J. F. (2018). Responses of Ten Weed Species to Microwave Radiation Exposure as Affected by Plant Size. Journal of Environmental Horticulture, 36(1), 14-20.

Rüegg, W. T., Quadranti, M., \& Zoschke, A. (2007). Herbicide research and development: challenges and opportunities. Weed Research, 47(4), 271-275.

Sahin, H. (2012). Tarımsal Üretimde Yabancı Ot Mücadelesinde Mikrodalga Yönteminin Uygulanabilirliğinin Belirlenmesi Üzerine Bir Araştırma, Doktora Tezi, Harran Üniversitesi Fen Bilimleri Enstitüsü. 
Sahin, H. (2019). $2.45 \mathrm{GHz}$ mikrodalga frekansının yabancı ot mücadele yöntemi olarak kullanılması. Harran Üniversitesi Mühendislik Dergisi, 4 (3), 58-71.

Sahin, H. (2020). Investigating the effect of single and multiple electrodes on mortality ratio in electric current weed control method with NDVI technique. Journal of the Faculty of Engineering and Architecture of Gazi University, 35(4), 1973-1984.

Sahin, H., \& Yalınkılıc, M. (2017). Using Electric Current As A Weed Control Method. European Journal Of Engineering Research And Science, 2(6), 59-64.

Sahin, H., (2014). Effects of Microwaves on Germination of Weed Seeds. Journal of Biosystems Engineering, 39(4), 304-309.

Sahin, H., and Saglam, R. (2015). Research about microwave effects on the weed plants. J Agr Biol Sci, 10, 79-84.

Salisbury, F. B. and Ross, C. W. (1992). Plant Physiology, Wadsworth, Belmont, California, USA, 4th edition.

Schinasi, L. H., Quick, H., Clougherty, J. E., \& De Roos, A. J. (2019). Greenspace and Infant Mortality in Philadelphia, PA. Journal of Urban Health, 96(3), 497506.

Skiles, J. W. (2006). Plant Response To Microwaves At 2.45 GHz. Acta Astronautica, 58(5), 258-263.

Shaner, D. L., \& Beckie, H. J. (2014). The future for weed control and technology. Pest management science, 70(9), 1329-1339.
Solomon, K. R., Dalhoff, K., Volz, D., \& Van Der Kraak, G. (2013). Effects of herbicides on fish. In Fish physiology (Vol. 33, pp. 369-409). academic press.

Spruce, J. P., Hicke, J. A., Hargrove, W. W., Grulke, N. E., \& Meddens, A. J. (2019). Use of MODIS NDVI Products to Map Tree Mortality Levels in Forests Affected by Mountain Pine Beetle Outbreaks. Forests, 10(9), 811.

Taheri, S., Brodie, G., Jacob, M. V., \& Antunes, E. (2018). Dielectric Properties of Chickpea, Red and Green Lentil in The Microwave Frequency Range as a Function of Temperature and Moisture Content. Journal of Microwave Power and Electromagnetic Energy, 1-17.

Van Emmerik, Tim, et al. (2016). Dielectric response of corn leaves to water stress. IEEE Geoscience and Remote Sensing Letters, 14.1: 8-12.

Velazquez-Martí, B., Gracia-López, C., \& De La Puerta, R. (2008). Work Conditions For Microwave Applicators Designed To Eliminate Undesired Vegetation in $A$ Field. Biosystems Engineering, 100(1), 31-37.

Villeneuve, P. J. (2017). Urban greenness and mortality in Canada's largest cities: a national cohort study. The Lancet Planetary Health, 1(7), e289-e297.

Zimdahl, R. L. (2018). Fundamentals of weed science. Academic press. 